\title{
INNOVATIONS in pharmacy
}

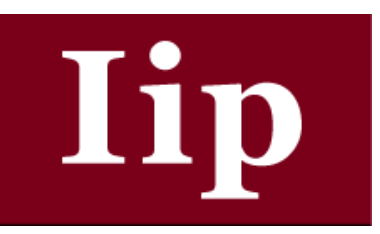

Volume 7 Number 2

Article 9

$7-1-2016$

Imaginary Worlds: Modeled claims for costeffectiveness published in PharmacoEconomics January 2015 to December 2015

Paul C. Langley

University of Minnesota, langley@maimonresearch.com

Follow this and additional works at: http://pubs.lib.umn.edu/innovations

\section{Recommended Citation}

Langley PC. Imaginary Worlds: Modeled claims for cost-effectiveness published in PharmacoEconomics January 2015 to December 2015. Inov Pharm. 2016;7(2): Article 9. http://pubs.lib.umn.edu/innovations/vol7/iss2/9

INNOVATIONS in pharmacy is published by the University of Minnesota Libraries Publishing. 


\title{
Imaginary Worlds: Modeled claims for cost-effectiveness published in PharmacoEconomics January 2015 to December 2015
}

\author{
Cover Page Footnote \\ I would like to thank $\mathrm{T} G$ Rhee for his assistance in collating the papers to be reviewed
}




\title{
Imaginary Worlds: Modeled claims for cost-effectiveness published in PharmacoEconomics January 2015 to December 2015
}

Paul C. Langley, PhD

College of Pharmacy University of Minnesota

\begin{abstract}
The purpose of this review is to assess whether or not economic evaluation studies published in PharmacoEconomics in 2015 meet the standards of normal science. Two questions are key to the assessment: (i) did the authors attempt to generate testable claims as to the impact of the pharmaceutical product in health care systems and (ii) did the authors suggest how the claims might be evaluated? A total of 31 studies were evaluated, including 14 research articles, 8 systematic reviews and 9 reviews. Although the majority of the studies met recommended standards for cost-effectiveness analysis, none met the standards of normal science. They were best categorized as imaginary worlds or thought experiments. The reader has no idea whether the claims for the products are right or even if they were wrong. Journal editors have two options: (i) require authors to submit cost-effectiveness claims that are evaluable with a protocol suggesting how the claim may be evaluated or (ii) continue to publish non-evaluable cost-effectiveness claims but insist authors indicate that the claims are non-evaluable.
\end{abstract}

\section{Introductions}

A number of recent publications have raised doubts as to the status of modeled cost-effectiveness claims in pharmacoeconomics ${ }^{1234}$. The primary concern has been with the construction of modeled thought experiments (or imaginary worlds) to support claims for comparative costeffectiveness. Rather than the development of models to generate testable claims or predictions for the anticipated impact of new products and devices in health care systems, the modeled claims are seen as an end in themselves.

Unfortunately, readers are not advised, as a matter of course, that non-evaluable cost-effectiveness claims should not be taken at face value.

If a modeled claim is impossible to assess or if the model fails to generate testable claims, then the model fails to meet the standards of normal science. These standards are absolute and have been recognized since the 17th century. The core elements being: (i) the construction of empirically evaluable coherent theories and (ii) the testing of hypotheses through experimentation or systematic observation.

Empirical testability differentiates science from non-science or pseudoscience. Irrespective of whether or not the authors of a model argue that it is a reasonable reflection of reality, a correspondence that is sufficient and necessarily entails the claims made, the absence of testable claims means that the

Corresponding author: Paul C Langley, PhD

Adjunct Professor

College of Pharmacy University of Minnesota

Phone: 520-577-0436

Email: langley@maimonresearch.com

Web: www.maimonresearch.com model should be put to one side. This may involve a reconsideration of the model to assess whether or not it is capable of being recast to generate testable claims. If the model is incapable of generating testable claims then it should be rejected.

In the absence of experimentation or observation, a formulary committee has no idea whether modeled claims are right or even if they are wrong. To an unknown and unknowable extent the claims may be misleading and even potentially harmful. Acceptance of the standards of normal science is in contrast, therefore, to a postmodern or relativist position which holds that if the model intends to reflect reality then, given the consensus view within the profession, we should accept the claims made and to factor them, even though they are impossible to evaluate, into formulary decisions.

While a debate over philosophical positions may seem something of a stretch when we address issues of costeffectiveness modeling, the acceptability or otherwise of modeled claims is critical to an assessment of the worth of pharmacoeconomic modeling to support value claims. If we conclude that modeled yet untestable claims should be rejected as a basis for decision making, then we face the prospect of rejecting much of the modeling endeavors over the past 25 to 30 years as well as guidelines for good practice and recommendations for formulary submissions. If we accept the relativist position that modeled claims, even if untestable, are still credible as thought experiments or imaginary worlds then we run the risk of losing status as a 'science' in our rejection of the standards of normal science that underpin our belief in the discovery of new facts. 
The purpose of this review is to evaluate the costeffectiveness or economic evaluation studies that have been published in PharmacoEconomics in the period January 2015 to December 2016. This evaluation is part of an ongoing program at the College of Pharmacy, University of Minnesota exploring the credibility of cost-effectiveness claims; to see whether published claims meet the standards for falsification and replication that are the core of the scientific method.

\section{Methods}

A systematic review, following the PRISMA-P checklist (MeSH terms 'cost', 'cost-effectiveness', 'QALY'), of all papers published in PharmacoEconomics in the period January 2015 to December 2016 identified 31 economic evaluation studies ${ }^{5}$. These comprised 14 original research articles, 8 systematic reviews and 9 reviews. These studies are detailed in Table 1.

In order to judge whether the modeled claims presented or reviewed met the standards of normal science, four questions were considered:

- Is the model capable of generating testable claims?

- Did the author(s) attempt to generate testable claims?

- Did the author(s) suggest how the claims might be evaluated?

- Did the author(s) caution readers as to the implications of generating non-testable claims?

A testable claim was defined as one that could be evaluated either experimentally or observationally in a timeframe relevant to the needs of a formulary committee (ideally a period of 2 to 3 years). This period was chosen because a testable claim was seen as provisional; a condition established in the WellPoint formulary guidelines issued almost a decade ago. ${ }^{67}$. A product or device could, in this context, be accepted by a formulary committee for provisional listing, but subject to an agreement with the manufacturer to report back to the committee with evidence to support the claims made. These claims could be for product comparative effectiveness, for the impact of the product on resource utilization or some combination of these to support a claim for incremental costeffectiveness. The claim for comparative effectiveness could encompass clinical endpoints as well as those captured as patient reported outcomes.

The important point to note is that the modeled claims were not to be judged on the reasonableness or otherwise of the assumptions of the model; a point made recently by Ellis and Silk in reference to claims in string theory modeling ${ }^{8}$. The fact that the claims could not be tested led to those supporting string theory to argue that the inherent elegance of a model should be sufficient for its acceptance, without need to evaluate any testable claims. Ellis and Silk pointed out that this was unacceptable if the standards of normal science were to hold.

Certainly a cost-effectiveness model would be expected to cover comparator products, or least the key comparators, and to identify the target population for the claims. But this does not mean a model should necessarily conform to recommended standards from organizations such as the International Society for Pharmacoeconomics and Outcomes Research (ISPOR) or to items such as the CHEERS checklist ${ }^{9} 10$ 111213 . While the CHEERS checklist has been embraced by a number of journals, the point is that neither ISPOR recommended standards for good practice or the CHEERS checklist have endorsed the standards of normal science in accepting the central role of claims assessment. In this review there was no attempt to censor or categorize the studies reviewed by such criteria, although given that PharmacoEconomics subscribes to the CHEERS checklist, it was assumed that these criteria would have been addressed as part of the peer review process.

In judging whether or not a model might support testable claims, even if the possibility was not considered by the authors(s), three characteristics of the model are important. These are (i) the modeling framework, (ii) the choice of primary outcome measure; and (iii) the time frame for the model. A Markov or discreet event simulation model with a lifetime perspective and with discounted cost per quality adjusted life year (QALY) claims as the primary endpoints would be one that would be impossible to evaluate. Against this, a simple, trial-based decision model with a timeframe of 12 to 18 months with claims expressed in clinical terms (including PROs) and resource utilization endpoints would, given access to readily available data sources in the US, be open to hypothesis testing and feedback to a formulary committee.

In the case of the systematic reviews and reviews, the focus was on, not the individual papers but on the whether or not the reviewer took into account the issue of whether the models presented in the papers under review were capable of generating testable claims, whether any attempts were made to evaluate claims and whether the authors made any suggestions as to how the claims made might be evaluated by, for example, a formulary committee as part of ongoing disease area and therapeutic reviews. A number of these reviews utilized a checklist to evaluate the 'quality' of the study, such as the CHEERS or the Quality of Health Economics Studies (QHES) checklist ${ }^{14}$. The QHES checklist does not consider either the ability to generate testable claims or proposals for how claims might be evaluated as part of a quality assessment. 
A study may be judged 'high quality' by application of the QHES or CHEERS checklist but still may fail to meet the standards of normal science. It may meet the National Institute for Health and Care Excellence (NICE) reference case standards, but as a result fail to provide operational content in meeting the standards of normal science ${ }^{15}$. Irrespective of the internal 'mathematical elegance' of the cost-effectiveness model, it would be considered by the standards of normal science to be what is described here as an imaginary world or thought experiment.

\section{Results}

\section{Original Research Articles}

The primary outcome measure in 13 of the 14 original research articles was incremental cost-per-QALY. Subsidiary endpoints included costs, years of life gained and events avoided (e.g., falls). In a number of the articles discount rates were applied to both costs and outcomes to yield discounted cost-per-QALY claims. The majority of the papers, although not necessarily stating it explicitly, attempted to follow NICE reference case standards or those proposed by ISPOR for good modeling standards in generating estimates of direct medical costs and utilizing a generic QALY measure. None of the models utilized measures of generic QALYS generated directly from the comparative products' RCTs. The only paper that reported cost-per-QALYs from a trial generated these indirectly from the SF-12v2 instrument utilized in the trial ${ }^{24}$. Other studies mapped utility values from other instruments or captured utilities from studies in 'similar' product scenarios.

With the exception of one paper, all utilized a Markov statetransition model framework. The timeframes for the various state transition models ranged from 5 years to the lifetime of the modeled cohort. Seven of the articles employed a time frame of 30 years or longer (4 the lifetime of the cohort) and 4 articles reported on a 10 year timeframe. In the case of the lifetime models, three of these focused on either older patients (with limited lifespans) or those whose health states were in the end stage of the disease. The youngest lifetime cohort at age 40 years was modeled for dermatomysotis, with 56 years for hyperphosphataemia, 70 years for atrial fibrillation and 84 years for injury prevention.

In respect of the questions raised for this review, none of the studies presented considered how the claims made might be evaluated. None of the studies presented testable claims. There were no discussions of how these modeled claims might be factored into formulary decisions. Discussions on the limitations of the studies focused on the deficiencies in the evidence base used to populate the model parameters, the presence of significant evidence gaps, the lack of direct generic QALY measures for the target populations, the difficulty of translating costs estimates across health systems and the degree of uncertainty attached to the modeled claims for comparative effectiveness.

\section{Systematic Reviews}

Five of the 8 systematic reviews utilized a quality assessment checklist to grade the individual studies: 3 papers used the CHEERS checklist while 3 utilized the QHES checklist. Zhang et al concluded that of the 53 studies evaluated in psoriasis the majority were of low quality. In their view high quality studies should apply a reasonably long time horizon (with $30 \%$ adopting a time horizon of $<1$ year), adopt a valid and comparable effectiveness measure (QALY), consider all relevant cost items and conduct a sensitivity analysis ${ }^{31}$. The question of whether or not the model should be capable of generating testable hypotheses was not considered. Hiligsman et al in their review of postmenopausal osteoporosis drugs also reported on an insufficient quality of reporting for several articles $^{30}$. These included methods for identifying and synthesizing clinical effectiveness data, the description of the population and methods used to value preference based outcomes (all but one of the studies used QALYs as the outcome measure) and all analytic methods supporting the evaluation. Again, the question of whether or not the model should be capable of generating testable hypotheses was not considered. None of the reviews raised any questions as to the appropriateness of Markov models in generating testable predictions and the implications for evaluating model findings where, for example, the timelines of the models ( 9 out of 20 Markov simulations modeled claims for 40 years or more).

The most frequently cited outcomes were QALYs and life years gained (LYG). In postmenopausal osteoporosis, 38 out of 39 studies used QALYs; in psoriasis PASI (Psoriasis Area and Severity Index) were reported in 26 studies and QALYs in 15 studies (out of a total of 53 studies) ${ }^{30}$; in diabetes all 11 studies reported QALYs ${ }^{34}$; in tuberculosis QALYs were the outcome measure in 15 studies and TB cases prevented in 7 studies (out of 24 studies) ${ }^{35}$; in gout the humanistic burden was reported as either generic or disease specific $\mathrm{HRQoL}{ }^{36}$; and in ovarian cancer, out of 28 studies, 15 studies reported cost per LYG and cost per QALY in 13 studies ${ }^{38}$. Once again, the question of testable claims was not raised or even how differences in comparative cost-per-QALY claims within disease or therapeutic areas or for individual products across the various studies might be resolved. The issue of whether QALYs could actually be evaluated or their absence in administrative claims or other health data sets was not raised. Any comparison is made the more difficult, presumably, given the disparate instruments and matching (or crosswalking) techniques employed in generating utility scores. There was no discussion of how these disparities might be resolved. Review Articles 
Eight of the 9 review articles reported the findings of NICE single technology appraisals (STA) 3940414344454647 . Under the STA process manufacturers are invited to submit a clinical and cost-effectiveness case for a product in seeking a recommendation within its marketing authorization. The role of the Evidence Review Group (ERG) is to evaluate the submission, possibly seek additional input from the manufacturer, and if necessary develop its own model and report to the NICE Advisory Committee. The ERG report is considered by the NICE Appraisal Committee, with (after possibly further review) a final recommendation, and a NICE guidance. Outside of NICE, there is no independent review of findings.

The focus of the ERG's evaluation of single product submissions is on the validity of the underlying clinical claims that are made, typically the techniques applied to indirect product comparisons, and the structure and assumptions of the submitted cost-effectiveness model. The critical questions are: (i) whether the evidence submitted conforms to the methodological guidelines issued by NICE; (ii) whether the company's interpretation of the evidence is appropriate; and (iii) whether there are other evidence sources or alternative interpretations that could be useful. In respect of the reference case cost-effectiveness model the ERG is required (i) to comment on the robustness and accuracy of the model; (ii) the data used to populate the data used to populate the mode; and where possible (iii) to carry out a sensitivity analysis.

None of the eight STAs reviewed gave any recognition to the possibility of modeled claims generating testable predictions, as to how possible claims might be evaluated or whether recommendations might be revisited if additional evidence emerges that challenged the ERG summaries of clinical and cost-effectiveness claims. Instead, the focus of the STA is on checking and challenging modeled assumptions. These challenges range from the choice of clinical data, the techniques applied for indirect comparisons on clinical effect, the relevance of trial protocols to the target UK population, the choice of model, the choice of health states, the state transition probabilities, cycle lengths, application of survivorship techniques, the measurement of utilities and the scope of resource units and costs. The model is checked against the gold standard of the reference case.

While standards for developing evaluable predictions, falsification and replication are outside the reference case remit, three off the products reviewed had the potential for generating comparative evaluable claims. These are: alteplase for ischaemic stroke; aflibercept for metastatic colorectal cancer and ipilimumab for unresectable malignant melanoma 414347 . The models proposed could be modified to generate assessable claims, given the expected survival profiles in these late-stage interventions at (say) six or 12 months.

\section{Discussion}

There is no doubting the popularity of modeled claims in the health technology assessment literature; models which in the majority cases conform to the standards proposed in checklists such as CHEERS and QHES. Unfortunately, the conformity in these models to what are perceived as 'quality standards', exemplified in the NICE reference case, means (i) they fail to meet the standards of normal science and (ii) are unlikely, outside of groups such as NICE in the UK, the PBAC in Australia, the AMCP in the US and CADTH in Canada to be of interest to formulary committees and other health system decision makers ${ }^{48} 4950$.

The accepted models can extend, in the case of chronic disease, for the lifetime of the patient cohort. Commonly applying Markov models or the more mathematically complex discreet event modeling, the analyst presents results in terms of the recommended gold standard outcome measure of lifetime quality adjusted life years saved, claiming benefits from one product over another. The models are justified by their ability to 'reflect reality', a present and future reality of 'what is', in choice of target population characteristics, treatment arms, assumed resource utilization and costs and outcomes defined by constructed quality of life indices. The models rely for their appearance of 'reasonableness' on their foundation in disparate (yet peer reviewed) literature sources and results reported for RCTs. With due account taken in the modeling technique of parameter and outcome uncertainty, the models are presented as evidence for the comparative effectiveness of competing therapies.

Can this practice be justified? Can we make claims for the comparative impact of competing products that might extend decades into the future and expect them to be taken seriously? Could we argue, for example, that the modeled claims 'reflect reality' and that they should be considered as equivalent to modeled claims that generate testable hypotheses which can be evaluated from existing evidence; an appeal to the facts?

\section{The Standards of Normal Science}

The fact that the modeled or simulated claim is defended on the grounds that it 'reflects reality' or that it is 'reasonable' in is representation or correspondence to the target treating environment and the anticipated impact of competing products and devices in not, unfortunately, a justification for accepting the model and claims generated as supporting coverage decisions. If a formulary committee is to consider modeled claims as a basis for a coverage decision then the model claims need to meet the standards of normal science: 
the claims should be capable of experimental or observational evaluation. If not, the model and the claims should be put to one side as 'not fit for purpose'.

If a model is said to 'reflect reality' the obvious questions are 'what is reality' and what is a 'reflection'? From the perspective of the model builder (or collaborative group of model builders), the reality they perceive is presumably the state of things that they think actually exists and are 'expected' to exist over the time frame of the model (an imaginary future); their belief in the simulation's correspondence with the real world. If the correspondence is sufficient, then the outcomes claimed are necessarily entailed.

Unfortunately, no two groups may share the same vision of correspondence with the real world. The NICE Evidence Review Group (ERG) may not agree with the manufacturer's submission. Their different realities may generate different models which, while subscribing to the same set of standards, may result in quite different non-testable claims for the superiority of the same competing products. This presents a quandary to a formulary committee where competing models jostle for attention. Whose claims should be accepted? Should the formulary committee attempt to set 'acceptable' modeling parameters, as in the NICE reference case, in order to ring-fence modeling options? Even so, there is still the possibility that different groups will propose different models. Indeed, manufacturers may support competing models that meet common standards. Both are justified on the grounds that they 'reflect reality'. Both are defended on the grounds that they meet the required standards of the commonly held belief system.

\section{Feedback, Information, Evidence}

As noted above, neither the CHEERS nor the QHES checklists address the question of whether or not the studies evaluated are capable of generating testable predictions. There is no concept of how, through evaluating claims, new facts might be uncovered. There is also no concept of how claims evaluation may generate feedback to formulary committees and other health decision makers. The view seems to be that this approach is too difficult, time consuming and of little interest to decision makers; building imaginary worlds which have little if any chance of creating testable predictions is the easy option.

Another argument for 'accepting' modeled claims even if they fail to generate testable hypotheses is that we have limited information. Even though the US is well served in access to health data, ranging from administrative claims, possibly linked to laboratory data, together with electronic medical records from in-patient and ambulatory environments, the rest of the world is less well served. Our ability to assess claims for competing products and devices, particularly if we wish to capture patient reported outcomes as a primary endpoint, means that we may either to invest significant resources in data capture in targeted treatment settings or we have to rely on a less resource intensive approach to supporting claims. As a result, it could be argued, we fall back to a 'needs must' justification with our belief in comparative modeled claims driving our research agenda and formulary decisions.

The NICE reference case is clearly not designed to generate empirically evaluable claims. It rejects the standards of normal science. Rather, subject to the ministrations of contracted academic assessment centers, manufacturer's submissions are scrutinized; models are tinkered with, adjustments are made to cost-per-QALY claims and thresholds re-calibrated. This sets the stage for pricing negotiations and agreement on the terms for formulary listing - all driven by an imaginary construct which, in most cases, is a reformulation of an earlier imaginary construct.

NICE arrives at a determination on the acceptability of a product, couched in terms of threshold cost-per-QALY performance. As these claims for threshold performance are impossible to validate, there is little chance that the NICE decision can be effectively challenged (other than though public opinion and the redoubtable 'Daily Mail'). Paradoxically, while there is presumably evidence to justify building the imaginary reference case, there is no appeal to evidence to validate claims made. Indeed, the reference case itself ensures, whether intentional or not, that the evidence is most unlikely ever to eventuate to question NICE decisions. This is seen in what Popper refers to as the problem of demarcation given the possibility, which distinguishes empirical science from pseudoscience, of immunizing any theory against criticism ${ }^{51}$.

What this process overlooks is the fact, as noted by Popper, that never in science are inferences drawn from mere observational experience to the prediction of future events ${ }^{51}$. There is no sense, in these single technology appraisals of any interest in (or any commitment to) a program to discover new facts.

\section{Equivalent Belief Systems}

There is, however, a school of thought that could, its adherents would argue, defend the role of imaginary worlds in decision making: relativism. A relativist subscribes to what is known as the equivalence postulate. This postulate holds that it is illegitimate to maintain that one belief system is superior to another. We cannot argue for 'superiority' because we have 'good evidence' for it; in other words, because we have validated a belief or claim by an appeal to the evidence. Application of the standards of normal science is not, for a 
relativist, a means of coming to grips with reality. From a sociological perspective, for the relativist (or postmodernist) to accept the standards of normal science in accepting or rejecting claims is to say that one belief system is superior to another; a position which is unacceptable if we accept the equivalence of all belief system ${ }^{52}$. Discovery is put to one side in favor of rhetoric, persuasion and authority ${ }^{53}$.

For a relativist the focus is on constructing truth ${ }^{54}$. If there is a group that can convince others of their standards, then they have the power to create belief and decide what they would label 'knowledge'. The result is that modeled claims are not subject to the scrutiny that comes from generating and testing claims. Hypothesis testing is put to one side. The simulated or modeled claim is the end product.

If the objective is to 'construct truth' in the choice of model and its assumptions, then many of the models reviewed here rest on somewhat shaky empirical foundations. Study limitations detailed by authors include: limited clinical data, lack of clinical follow-up data, inappropriate clinical comparator data, lack of data on-follow up or secondary therapy choices, lack of data to support modeling state transition probabilities, limited direct medical cost data (particularly for second-line therapy), lack of indirect cost data, lack of non-clinical primary endpoint data (e.g., utility scores), reliance on underpowered secondary endpoints from clinical studies and an absence of therapy adherence data. Many of these limitations are self-inflicted, due to the longterm perspective of the model itself and the acceptance that the gold standard endpoint is the QALY.

PharmacoEconomics reports that over the past 30 years it has published over 3,000 papers. If the proportion of nonevaluable modeled claims published in the last 12 months are indicative of the weight given to those publications, then the journal has probably published over one thousand thought experiments to support claims for comparative effectiveness (not to mention publication of systematic reviews which bring in dozens more papers). If this is the case (and given the time span involved) a reasonable question might be to ask if any author has attempted to revisit modeled claims to evaluate whether those claims have been substantiated? After all, if the journal has been prepared to publish, say, a modeled costper-QALY claim for competing products over a 10 year timeframe, then it should have been possible in this timeframe to revisit this claim.

Acceptance of a belief system, of standards for establishing the superiority of comparative product claims that lies outside of the standards accepted for normal science, assumes that those making formulary decisions share that belief system. While this may be true in the UK where NICE and academic research groups have embraced the reference case model (and indeed these groups were party to its development), in a country such as the US there is little evidence for formulary committees or other health decision makers agreeing on the decision criteria for formulary listing. Given the literally thousands of formulary committees that have emerged following the passing of the Patient Protection and Affordable Care Act in 2010, it is most unlikely that any more than a minority are aware (or, at least adhere to) standards proposed by ISPOR and the format for formulary submissions recommended by the AMCP. It is even more unlikely that there are many that would subscribe to the reference case model. They would probably consider it rather odd to base decisions for product value on lifetime cost-per-QALY models, let alone base decisions on conformity of a claim that is patently non-evaluable to a notional threshold value.

The risk, therefore, is that a wider audience, the audience that comprises decision makers for pharmaceutical products, fails to share the decision standards for modeled claims. The effort put into modeling, systematic reviews and organizational frameworks may be seen, at best, to be odd, but irrelevant to ongoing formulary decisions which seek evidence-based value claims and feedback from prior claims for product performance.

\section{Rejecting Equivalence}

It is not possible to subscribe to competing belief systems. This is an impossible and indefensible position: either subscribe to the recognized standards of normal science or admit to participating in a pseudoscience. In other words, a metaphysical exercise which is intended to persuade rather than establish new facts; a belief system, from the relativist perspective, which has no claim to superiority over other belief systems. The reason for this is quite obvious: if a claim is not amenable to empirical testing then we don't know whether it is right or whether it is wrong. It may, to an unknown and unknowable extent, be misleading. As such, untestable claims should be relegated to the status of imaginary worlds or thought experiments; a relegation that is effectively summarized in the motto of the Royal Society (1660 first meeting; 1662 Royal Charter): nullius in verba ('take no man's word for it').

The task of relegating economic evaluations to the category of imaginary worlds can be resolved once we abandon attempts to apply standards for modeled claims that are inconsistent with the standards of normal science. Since the $17^{\text {th }}$ century, standards to be applied to modeled claims have been clearcut: a model is judged on the basis of the hypotheses or claims it creates; its ability to generate new facts. The first hurdle is to agree that the claims are testable, either through observation (e.g., an appeal to existing evidence) or through 
experiment (e.g. an RCT). The second hurdle is to test the claim. If the claim is not falsified then it receives provisional acceptance. All claims are provisional; subject to further evaluations which may overturn them. This process of 'conjecture and refutation', as described by Popper, is at the core of the scientific method ${ }^{55}$. It supports the notion of progress in science. It is a process that explores our understanding of the real world and sets the stage for generating, testing and the discovery (and exploration) of new facts.

\section{Conclusions}

Rejecting or recasting modeled claims that are 'not fit for purpose' is a necessary step, not only for the formulary committee but for other health care decision makers to recognize the importance of a firm and defensible evidence base for decision making. We can still, of course, subscribe to a hierarchy of evidence and work with decision makers to identify and, hopefully, close evidence gaps. In recognizing that modeled claims may not be fit for purpose does, however, raise the issue of whether or not the publication of modeled claims which are essentially imaginary worlds or thought experiments should be encouraged? Could we argue that they are suggestive of more tractable hypotheses, of projections, and should be published even if there is no assessable hypothesis presented? In the last resort it is presumably up to journal editors and staff to agree on whether or not they wish to subscribe to standards which are relativistic or culturally determined. Should they support postmodernist standards which are clearly at variance with those of normal science in publishing claims for comparative product performance? Or should they come out and declare support for clinical and cost-effectiveness models that drive a research agenda that meets the standards of normal science?

The position taken here is unambiguous: if claims based on imaginary worlds or thought experiments are published, the readership should be advised of this by the authors of the paper. This is not to deny the right to publication but merely to ensure that the evidence presented is 'fit for purpose'. If the editorial policy of a journal such as PharmacoEconomics is to subscribe to and support the beliefs accepted in a discipline such as pharmacoeconomics, then this should be made explicit, pointing out that these are not the standards of normal science.

\section{References}

1. Langley P. The status of modeled claims. J Med Econ. 2015;18(12):991-992

2. Langley P. Validation of modeled pharmacoeconomic claims in formulary submissions. J Med Econ. 2015;18(12):993-999

3. Schommer J, Carlson A, Rhee G. Validating pharmaceutical product claims: questions a formulary committee should ask. J Med Econ. 2015;18(12):10001006

4. Belsey J. Predictive validation of modeled health technology assessment claims: lessons from NICE. J Med Econ. 2015;18(12):1007-1012

5. Moher D, Shamseer L, Clarke E et al. Preferred reporting items for systematic reviews and met-analyses protocol (PRISMA-P) 2015 statement. Systematic Reviews. 2015;4:1 DOI: 10.1186/2046-4053-4-1

6. Langley PC. Recent developments in the health technology assessment process in Fulda TR, Wertheimer Al (eds). Handbook of Pharmaceutical Public Policy. New York: Pharmaceutical Products Press. 2007.

7. Sweet B, Tadlock CG, Waugh W et al. The WellPoint Outcomes Based Formulary: Enhancing the Health Technology Assessment Process. J Med Econ. 2005;8:1325

8. Ellis G, Silk J. Defend the integrity of physics. Nature. 2014 (516): 321323; see also A Frank and M Gleiser. A crisis at the edge of physics. New York Times, 7 June, 2015.

9. Marshall DA, Burgos-Liz L, ljzerman MJ et al. Applying dynamic simulation modeling methods in health care delivery research - the SIMULATE checklist: Report of the ISPOR Simulation Modeling Emerging Good Practices Task Force. Value Health. 2015;18:5-16

10. Marshall DA, Burgos-Liz L, ljzerman MJ et al. Selecting a dynamic simulation modeling method for health care delivery research - Part 2: Report of the ISPOR Dynamic Simulation Modeling Emerging Good Practices Task Force. Value Health. 2015;18:47-60

11. Caro JJ, Briggs A, Siebert $U$ et al. Modeling good research practices - Overview: A report of the ISPOR-SMDM Modeling good practices task force -1 . Value Health. 2012 (15:796-803

12. Eddy DM, Hollingworth W, Caro JJ et al. Model transparency and validation: A report of the ISPORSMDM modeling good research practices Task Force -7 . Value Health. 2012;15:843-850

13. Husereau $D$, Drummond $M$, Petrou $S$ et al. Consolidated health economics evaluation reporting standards (CHEERS) statement. J Med Econ. 2013;16(6):713-19

14. Chiou C-F, Hay JW, Wallace JF, et al. Development and validation of a grading system for the quality of costeffectiveness studies. Med Care. 2003;41:32-44.

15. National Institute for Health and Care Excellence. Guide to the Methods of Technology Appraisal. London: NICE, April 2013 
16. Sawyer LM, Wonderling D, Jackson K et al. Biological therapies for the treatment of severe psoriasis in patients with previous exposure to biological therapy: A cost-effectiveness analysis. PharmacoEconomics. 2015;33(2):163-177

17. Blank PR, Filipits M, Dubsky P et al. Cost-effectiveness of prognostic gene expression signature- based stratification of early breast cancer patients. PharmacoEconomics. 2015;33:179-90

18. Mensch A, Stock S, Stollenwerk B et al. Cost effectiveness of rivaroxaban for stroke prevention in German patients with atrial fibrillation. Pharmacoeconomics, 2015;33(3):271-83

19. Hamid R, Loveman C, Millen J et al. Cost-effectiveness analysis of onabvotulinumtoxin A (BOTOX) for the management of urinary incontinence in adults with neurogenic detrusor overactivity: A UK perspective. Pharmacoeconomics. 2015;33:381-93

20. Schawo S, van der Kolk A, Annemans $L$ et al. Probabilistic Markov model estimating cost-effectiveness of methylphenidate osmotic-release oral system versus immediate-release methylphenidate in children and adolescents: which information is needed? PharmacoEconomics. 2015;33:489-509

21. Delea TE, Amdahl J, Wang A et al. Cost-effectiveness of dabrafenib as a first-line treatment fin patients with BRAF V600 mutation-positive unresectable or metastatic melanoma in Canada. PharmacoEconomics. 2015;33(4):367-80

22. Janzic $A$, Kos M. Cost effectiveness of novel oral anticoagulants for stroke prevention in atrial fibrillation depending on the quality of warfarin anticoagulation control. PharmacoEconomics. 2015;33(4):395-408

23. Bamrungsawad N, Chaiyakunapruk N, Upakdee $\mathrm{N}$ et al. Cost-utility analysis of intravenous immunoglobulin for the treatment of steroid-refractory dermatomyositis in Thailand. PharmacoEconomics. 2015;33(5):521-31

24. Finkelstein EA, Kruger E, Karnawat S. Cost-effectiveness of Qsymia for weight loss. PharmacoEconomics. 2015;33:699-706

25. Vestergaard AS, Ehlers LH. A health economic evaluation of stroke prevention in atrial fibrillation: Guideline adherence versus the observed treatment strategy prior to 2012 in Denmark. PharmacoEconomics. 2015;33(9):967-79

26. Takabayashi N, Murata K, Tanaka S et al. Costeffectiveness of proton pump inhibitor co-therapy in patients taking aspirin for secondaty prevention of ischemic stroke. PharmacoEconomics. 2015;33:10911100

27. Schremser K, Rogowski WH, Adler-Reichel A et al. Costeffectiveness of an individualized first-line treatment strategy offering erlotinib based on EGFR mutation testing in advanced lung adenocarcinoma patients in Germany. PharmacoEconomics. 2015;33:1215-28
28. Church JL, Haas MR, Goodall S. Cost effectiveness of falls and injury prevention strategies for older adults living in residential aged care facilities. PharmacoEconomics. 2015;33:1301-10

29. Gutzwiller FS, Pfeil AM, Ademi Z et al. Cost Effectiveness of Sucroferric Oxyhydroxide Compared with Sevelamer Carbonate in the Treatment of Hyperphosphataemia in Patients Receiving Dialysis, from the Perspective of the National Health Service in Scotland. PharmacoEconomics. 2015;33(12):1311-24

30. Hiligsmann M, Evers SM, Sedrine WB et al. A systematic review of cost-effectiveness analyses of drugs for postmenopausal osteoporosis. PharmacoEconomics. 2015;33(3):205-24

31. Zhang W, Islam N, Ma C. Systematic review of costeffectiveness analyses of treatment for psoriasis. PharmacoEconomics, 2015;33(4):327-40

32. Woolacott N, Hawkins N, Mason A et al. Etanercept and efalizumab for the treatment of psoriasis: a systematic review. Health Technol Assess. 2006;10:1-233

33. Srivastava K, Thakur D, Sharma S et al. Systematic review of humanistic and economic burden of symptomatic chronic obstructive pulmonary disease. Pharmacoeconomics, 2015;33(5);467-488

34. Geng JG, Yu H, Mao Y et al. Cost-effectiveness of dideptidyl peptidase-4 inhibitors for type-2 diabetes. PharmacoEconomics. 2015;33(6):581-97

35. Diel R, Lampoenius N, Nienhaus A. Cost effectiveness of preventive treatment for tuberculosis in special high-risk populations. Pharmacoeconomics. 2015;33(8):783-809

36. Shields GE, Beard SM. A systematic revciew of the economic and humanistic burden of gout. PharmacoEconomics. 2015;33:1029-47

37. Zakiyah N, Postma MJ, Baker PN et al. Pre-eclampsia diagnosis and treatment options: A review of published economic assessments. PharmacoEconomics. 2015;33:1069:82

38. Poonawalla IB, Parikh RC, Du XL et al. Cost effectiveness of chemotherapeutic agents in targeted biologics in ovarian cancer: A systematic review. PharmacoEconomics. 2015;33:1155-85

39. Fleeman N, Bagust $A$, Beale $S$ et al. Pertuzuma in combination wlh trastuzumab and docetaxel for the treatment of HER2-positive metastatic or locally recurrent unresectable breast cancer. PharmacoEconomics. 2015;33:13-23

40. Greenhalgh J, Bagust A, Boiland A et al. Eribulin for the treatment of advanced or metastatic breast cancer: $A$ NICE single technology appraisal. PharmacoEconomics. 2015;33(2):137-148

41. Holmes M, Davis S, Simpson E. Alteplase for the treatment of acute ischaemic stroke: A NICE single technology appraisal; an evidence review group perspective. PharmacoEconomics. 2015;33:225-33 
42. Haas M, Lourenco R. Pharmacological management of chronic lower back pain: A review of cost-effectiveness. Pharmacoeconomics. 2015;33(6):561-69

43. Wade R, Duarte A, Simmonds M et al. The clinical and cost-effectiveness of aflibercept in combination with irinotecan and fluorouracil-based therapy (FOLFIRI) for the treatment of metastatic colorectal cancer which has progressed following prior oxaliplatin-based chemotherapy: a critique of evidence. Pharmacoeconomics . 2015;33(5):457-466

44. Stevenson M, Pandor A, Stevens JW et al. Nalmefene foir reducing alcohol consumptions in people with alcohol dependence: An evidence review group perspective of a NICE single technology appraisal. PharmacoEconomics. 2015;33(8):833-47

45. Fleeman N, Bagust A, Beale $S$ et al. Dabrafenib for treating unresectable, advanced or metastatic BRAF V600 mutation positive melanoma: An evidence review group perspective. PharmacoEconomics. 2015;33(9):893-904

46. Simpson EL, Davis S, Thokala P et al. Sipuleucel-T for the treatment of metastatic hormone-relapsed prostate cancer: A NICE single technology appraisal; an evidence review group perspective. PharmacoEconomics.

2015;33:1187-94
47. Giannopoulou C, Sideris E, Wade R et al. Ipilimumab for previously untreated malignant melanoma: A critique of the evidence. PharmacoEconomics. 2015;33:1269-79

48. Australian Government. Department of Health. Guidelines for preparing submissions to the Pharmaceutical Benefits Advisory Committee (version 4.4). Canberra: July 2013

49. Canadian Agency for Drugs and Technologies in Health. Guidelines for the Economic Evaluation of Health Technologies: Canada ( $3^{\text {rd }}$ Ed). CADTH: Ottawa, 2006

50. Academy of Managed Care Pharmacy. AMCP Format for Formulary Submissions, Version 4.0 April 2016

51. Popper KR. Objective Knowledge (Rev ed.) (Oxford: Clarendon Press, 1979)

52. Shapin S, Schaffer S. Leviathan and the Airpump:Hobbes, Boyle and the Experimental Life. Princeton: Princeton University Press, 1985.

53. Wootton D. The Invention of Science. New York: Harper Collins, 2015

54. Foucault, M. The Order of Things, London: Vintage Books, 1970 (1966)

55. Popper KR., The logic of scientific discovery .New York: Harper, 1959 
TABLE 1: IMAGINARY WORLDS: ECONOMIC EVALUATION STUDIES PHARMACOECONOMICS JANUARY 2015 TO DECEMBER 2015

\begin{tabular}{|c|c|c|c|c|}
\hline Paper (author) & $\begin{array}{l}\text { Target Population and } \\
\text { Intervention }\end{array}$ & Sponsor (if any) & Modeling Technique and Claims Status & $\begin{array}{l}\text { Claims Assessment } \\
\text { and Credibility }\end{array}$ \\
\hline \multicolumn{5}{|c|}{ Original Research Article } \\
\hline Sawyer et al ${ }^{16}$ & $\begin{array}{l}\text { Cost effectiveness of } \\
\text { sequential biologic } \\
\text { therapies in patients } \\
\text { with psoriasis exposed } \\
\text { to previous biologic } \\
\text { therapy }\end{array}$ & $\begin{array}{l}\text { National } \\
\text { Guideline } \\
\text { Centre (UK) } \\
\text { with funding } \\
\text { from NICE }\end{array}$ & $\begin{array}{l}\text { A two part model following the NICE } \\
\text { reference case recommendations with a } \\
\text { 10-year time horizon. Model divided into } \\
\text { an initial short 'trial' period built as a } \\
\text { simple decision tree and a longer term } \\
\text { Markov transition model with annual cycles } \\
\text { and half cycle correctives where patients } \\
\text { either continue care or drop out and move } \\
\text { to best supportive care. Outcomes: Cost } \\
\text { per QALY. Results: Further biologic therapy } \\
\text { for patients with psoriasis who have } \\
\text { previously been treated with a biologic may } \\
\text { be cost effective although considerable } \\
\text { uncertainty in results. }\end{array}$ & $\begin{array}{l}\text { No testable } \\
\text { hypotheses or } \\
\text { consideration given to } \\
\text { how the claims might } \\
\text { be evaluated in a } \\
\text { shorter term model as } \\
\text { a } 10 \text {-year time horizon } \\
\text { precludes claims } \\
\text { assessment }\end{array}$ \\
\hline Blank et al $^{17}$ & $\begin{array}{l}\text { Cost effectiveness of } \\
\text { prognostic gene } \\
\text { expression signature } \\
\text { based stratification of } \\
\text { early breast cancer } \\
\text { patients (EPclin) }\end{array}$ & $\begin{array}{l}\text { Part sponsor } \\
\text { Sividon } \\
\text { Diagnostics } \\
\text { GmbH }\end{array}$ & $\begin{array}{l}\text { A lifetime Markov state transition model } \\
\text { with } 3 \text { health states (disease free, } \\
\text { metastasis and death) and a 1-year cycle. } \\
\text { Comparing standard guidelines with } \\
\text { guidelines plus molecular tests. Outcomes: } \\
\text { cost per patient treated and QALYs. } \\
\text { Results: EPclin strategy was dominant with } \\
13.173 \text { QALYs and lower costs. [Note: the } \\
\text { study results support the sponsors } \\
\text { product]. }\end{array}$ & $\begin{array}{l}\text { No testable } \\
\text { hypotheses or } \\
\text { consideration given to } \\
\text { how the claims might } \\
\text { be evaluated in a } \\
\text { shorter term model as } \\
\text { a lifetime horizon } \\
\text { precludes claims } \\
\text { assessment }\end{array}$ \\
\hline Mensch $^{18}$ & $\begin{array}{l}\text { Cost-effectiveness of } \\
\text { rivaroxaban for stroke } \\
\text { prevention in German } \\
\text { patients with atrial } \\
\text { fibrillation }\end{array}$ & & $\begin{array}{l}\text { A Markov state-transition with } 6 \text { health } \\
\text { states model comparing fixed dose } \\
\text { rivaroxaban with variable dose warfarin. } \\
\text { Time line } 35 \text { yearas or death for patients } \\
\text { aged } 65 \text { years with monthly cycles. } \\
\text { Outcomes: cost per QALY. Results: QALY } \\
\text { adjusted life expectancy for rivaroxaban } \\
\text { arm } 11.06 \text { years vs. } 10.35 \text { years for } \\
\text { warfarin. Corresponding total costs } \\
€ 20,238 \text { and } € 9,464 \text {. }\end{array}$ & $\begin{array}{l}\text { No testable } \\
\text { hypotheses or } \\
\text { consideration given to } \\
\text { how the claims might } \\
\text { be evaluated in a } \\
\text { shorter term model as } \\
\text { a } 35 \text {-year time horizon } \\
\text { precludes claims } \\
\text { assessment }\end{array}$ \\
\hline Hamid et al $^{19}$ & $\begin{array}{l}\text { Cost-effectiveness of } \\
\text { BOTOX for } \\
\text { management of }\end{array}$ & $\begin{array}{l}\text { Allergan Ltd } \\
\text { (UK) }\end{array}$ & $\begin{array}{l}\text { Markov state-transition cost per QALY } \\
\text { model with 5-year time frame and } 6 \text { health } \\
\text { states. Treatment arms: supportive care + }\end{array}$ & $\begin{array}{l}\text { No testable } \\
\text { hypotheses or } \\
\text { consideration given to }\end{array}$ \\
\hline
\end{tabular}




\begin{tabular}{|c|c|c|c|c|}
\hline & $\begin{array}{l}\text { urinary incontinence } \\
\text { with neurogenic } \\
\text { detrusor overactivity }\end{array}$ & & $\begin{array}{l}\text { BOTOX versus best supportive care alone } \\
\text { (including anticholinergic drugs ACHDs). } \\
\text { Cycle length 6-weeks after week } 12 \text {. } \\
\text { Outcomes: cost per QALY (including } \\
\text { reduced frequency of UI). Results: BSC + } \\
\text { BOTOX resulted in an increase in } 0.4388 \\
\text { discounted QALYs gained with an increase } \\
\text { in costs of } £ 1,689 \text { over } 5 \text { years. [Note: the } \\
\text { study results support the sponsors } \\
\text { product]. }\end{array}$ & $\begin{array}{l}\text { how the claims might } \\
\text { be evaluated in a } \\
\text { shorter term model as } \\
\text { a } 5 \text {-year time horizon } \\
\text { precludes claims } \\
\text { assessment }\end{array}$ \\
\hline Schawo et al ${ }^{20}$ & $\begin{array}{l}\text { Cost-effectiveness of } \\
\text { methylphenidate } \\
\text { osmotic-release oral } \\
\text { systems (OROS) versus } \\
\text { immediate-release } \\
\text { methylphenidate (IR) } \\
\text { in children and } \\
\text { adolescents with } \\
\text { ADHD }\end{array}$ & Jansse-Cilag BV & $\begin{array}{l}\text { Markov state-transition model with four } \\
\text { states with a duration of 12-years. Patients } \\
\text { entered the model at } 6 \text { years of age } \\
\text { following ADHD treatment guidelines. Cycle } \\
\text { length of 1-day. Four states were: optimal } \\
\text { response, suboptimal response, treatment } \\
\text { stopped and remission (no medication). } \\
\text { Outcomes: cost per QALY (parent/caregiver } \\
\text { evaluation). Results: dominance of OROS } \\
\text { compared to IR. Note: the study results } \\
\text { support the sponsors product. }\end{array}$ & $\begin{array}{l}\text { No testable } \\
\text { hypotheses or } \\
\text { consideration given to } \\
\text { how the claims might } \\
\text { be evaluated in a } \\
\text { shorter term model as } \\
\text { a } 12 \text {-year time horizon } \\
\text { precludes claims } \\
\text { assessment }\end{array}$ \\
\hline Delea et al $^{21}$ & $\begin{array}{l}\text { Cost-effectiveness of } \\
\text { dabrafenib as first-line } \\
\text { treatment in BRAF } \\
\text { V600 metastatic } \\
\text { melanoma in Canada }\end{array}$ & GlaxoSmithKline & $\begin{array}{l}\text { A 5-year partitioned survival analysis model } \\
\text { with } 3 \text { health states and a cycle length of 1- } \\
\text { week. Base treatment naïve patients } \\
\text { comparing dabrafenib, dacarbazine and } \\
\text { vemurafenib. Time horizon 5-years. } \\
\text { Outcomes: incremental cost per QALY } \\
\text { adjusted life year. Results: dabrafenib } \\
\text { unlikely to be cost-effective compared to } \\
\text { dacarbazine; no reliable conclusions } \\
\text { regarding dabrafenib versus vemurafenib }\end{array}$ & $\begin{array}{l}\text { No testable } \\
\text { hypotheses or } \\
\text { consideration given to } \\
\text { how the claims might } \\
\text { be evaluated although } \\
\text { the time line for the } \\
\text { model is only } 5 \text { years } \\
\text { and data accessible for } \\
\text { 2-3 year observational } \\
\text { study }\end{array}$ \\
\hline Janzic et al $^{22}$ & $\begin{array}{l}\text { Cost-effectiveness of } \\
\text { novel oral } \\
\text { anticoagulants } \\
\text { (NOACs) for stroke } \\
\text { prevention in atrial } \\
\text { fibrillation }\end{array}$ & & $\begin{array}{l}\text { Lifetime state transition Markov model } \\
\text { comparing dabigatran, rivaroxaban, } \\
\text { apixaban, high-dose edoxaban with } \\
\text { standard warfarin treatment. Starting } \\
\text { cohort 70-years of age with increased risk } \\
\text { for stroke. Outcomes: cost-per-QALY saved. } \\
\text { Results: NOACs more likely to be cost- } \\
\text { effective in settings with poor warfarin } \\
\text { management }\end{array}$ & $\begin{array}{l}\text { No testable } \\
\text { hypotheses or } \\
\text { consideration given to } \\
\text { how the claims might } \\
\text { be evaluated in a } \\
\text { shorter term model as } \\
\text { a lifetime time horizon } \\
\text { precludes claims } \\
\text { assessment }\end{array}$ \\
\hline $\begin{array}{l}\text { Bamrungsawad } \\
\text { et al }\end{array}$ & $\begin{array}{l}\text { Cost-utility of } \\
\text { Intravenous } \\
\text { Immunoglobulin (IVIG) }\end{array}$ & & $\begin{array}{l}\text { Markov four state-transition model with a } \\
\text { 12-week cycle for the lifetime of patients } \\
\text { initiating therapy at age of } 40 \text { years. }\end{array}$ & $\begin{array}{l}\text { No testable } \\
\text { hypotheses or } \\
\text { consideration given to }\end{array}$ \\
\hline
\end{tabular}




\begin{tabular}{|c|c|c|c|c|}
\hline & $\begin{array}{l}\text { in steroid-refractory } \\
\text { dermatomyositis in } \\
\text { Thailand }\end{array}$ & & $\begin{array}{l}\text { Outcomes: cost-per-QALY saved. Results: } \\
\text { IVIG dominant }\end{array}$ & $\begin{array}{l}\text { how the claims might } \\
\text { be evaluated in a } \\
\text { shorter term model as } \\
\text { a lifetime time horizon } \\
\text { precludes claims } \\
\text { assessment }\end{array}$ \\
\hline $\begin{array}{l}\text { Finkelstein et al } \\
24\end{array}$ & $\begin{array}{l}\text { Cost-effectiveness of } \\
\text { Qsymia for weight loss }\end{array}$ & VIVUS Inc & $\begin{array}{l}\text { A 56-week trial based estimate of cost and } \\
\text { QALY outcomes (imputed from SF-12v2). } \\
\text { Outcomes: Cost per QALY over } 1 \text { and } 2 \\
\text { years with residual benefits in years } 3 \text { and } \\
\text { 4. Linear regression modeling of change in } \\
\text { QoL as dependent variable and treatment } \\
\text { arm. Analogous regressions for PCS and } \\
\text { MCS scores. Imputed direct costs. Results: } \\
\text { Qsymia cost-effective at } \$ 50.000 \text { threshold. } \\
\text { May be cost-effective vs surgery if benefits } \\
\text { associated with therapy extend beyond } \\
\text { medication cessation. }\end{array}$ & $\begin{array}{l}\text { Although no testable } \\
\text { hypotheses or } \\
\text { consideration given to } \\
\text { how the claims might } \\
\text { be evaluated in an } \\
\text { observational study, } \\
\text { the short time-horizon } \\
\text { makes testing claims } \\
\text { achievable from } \\
\text { existing data }\end{array}$ \\
\hline $\begin{array}{l}\text { Vestergaard et } \\
\text { al }^{25}\end{array}$ & $\begin{array}{l}\text { Cost-effectiveness of } \\
\text { competing strategies } \\
\text { for stroke prevention } \\
\text { in atrial fibrillation }\end{array}$ & & $\begin{array}{l}\text { Markov state-transition model to simulate } \\
\text { costs and outcomes of two treatment } \\
\text { strategies of guideline adherence versus } \\
\text { observed treatment strategy over 10-year } \\
\text { time horizon with a 3-month cycle length } \\
\text { and a starting age of } 70 \text { years. Outcomes: } \\
\text { cost-per QALY saved over } 10 \text { years. Results: } \\
\text { Guideline adherence was cost-effective. }\end{array}$ & $\begin{array}{l}\text { No testable } \\
\text { hypotheses or } \\
\text { consideration given to } \\
\text { how the claims might } \\
\text { be evaluated in a } \\
\text { shorter term model as } \\
\text { a } 10 \text {-year time horizon } \\
\text { precludes claims } \\
\text { assessment }\end{array}$ \\
\hline $\begin{array}{l}\text { Takabayashi et } \\
\text { al }^{26}\end{array}$ & $\begin{array}{l}\text { Cost effectiveness of } \\
\text { proton pump co- } \\
\text { therapy in patients } \\
\text { taking aspirin for } \\
\text { stroke secondary } \\
\text { prevention }\end{array}$ & $\begin{array}{l}\text { None but } \\
\text { authorship } \\
\text { potential } \\
\text { conflict of } \\
\text { interest }\end{array}$ & $\begin{array}{l}\text { Markov state-transition model-based } \\
\text { simulation of one-year cycle with half-cycle } \\
\text { correction and a time horizon of } 30 \text { years. } \\
\text { Outcomes: life years gained with } \\
\text { willingness to pay threshold of US\$48,077 } \\
\text { and lifetime risk calculated from probability } \\
\text { of one health state divided by total of } \\
\text { probabilities of all health states. Results: } \\
\text { ASA plus PPI co-therapy cost-effective vs } \\
\text { ASA in Japan. }\end{array}$ & $\begin{array}{l}\text { No testable } \\
\text { hypotheses or } \\
\text { consideration given to } \\
\text { how the claims might } \\
\text { be evaluated in a } \\
\text { shorter term model as } \\
\text { a } 30 \text {-year time horizon } \\
\text { precludes claims } \\
\text { assessment }\end{array}$ \\
\hline $\begin{array}{l}\text { Schremser et al } \\
27\end{array}$ & $\begin{array}{l}\text { Cost-effectiveness of } \\
\text { epidermal growth } \\
\text { factor recipient } \\
\text { receptor (EGFR)- } \\
\text { tyrosine kinase } \\
\text { inhibitors as first line }\end{array}$ & $\begin{array}{l}\text { German } \\
\text { Research Center } \\
\text { for } \\
\text { Environmental } \\
\text { Health }\end{array}$ & $\begin{array}{l}\text { Markov state-transition model with } 3 \\
\text { mutually exclusive health states with a } \\
\text { cycle length of } 3 \text { weeks and a time horizon } \\
\text { of } 10 \text { years (assumed patient's lifetime). } \\
\text { Outcomes: cost-per-QALY. Results: } \\
\text { Individualized therapy with EGFR likelihood }\end{array}$ & $\begin{array}{l}\text { No testable } \\
\text { hypotheses or } \\
\text { consideration given to } \\
\text { how the claims might } \\
\text { be evaluated in a } \\
\text { shorter term model as }\end{array}$ \\
\hline
\end{tabular}




\begin{tabular}{|c|c|c|c|c|}
\hline & $\begin{array}{l}\text { therapy with erlotinib } \\
\text { in advanced lung } \\
\text { adenocarcinoma }\end{array}$ & & $\begin{array}{l}\text { of } 50 \% \text { cost-effective over standard } \\
\text { therapy. }\end{array}$ & $\begin{array}{l}\text { a } 10 \text {-year time horizon } \\
\text { precludes claims } \\
\text { assessment }\end{array}$ \\
\hline Church et al $^{28}$ & $\begin{array}{l}\text { Cost effectiveness of } \\
\text { falls and injury } \\
\text { prevention strategies }\end{array}$ & & $\begin{array}{l}\text { A three-state Markov lifetime transition } \\
\text { model with a cycle length of 1-year based } \\
\text { on starting mean age of residents in care } \\
\text { facilities ( } 84 \text { years). Outcomes: falls } \\
\text { avoided and QALYs gained. Results: vitamin } \\
\text { D supplementation, medication review } \\
\text { multifactorial interventions yield QALYs } \\
\text { gained and fall averted compared to no- } \\
\text { intervention. In cost-effectiveness terms } \\
\text { Vitmain D and medication are dominant. }\end{array}$ & $\begin{array}{l}\text { No testable } \\
\text { hypotheses or } \\
\text { consideration given to } \\
\text { how the claims might } \\
\text { be evaluated in a } \\
\text { shorter term model as } \\
\text { a lifetime horizon } \\
\text { precludes claims } \\
\text { assessment }\end{array}$ \\
\hline $\begin{array}{l}\text { Gutzwiller et al } \\
29\end{array}$ & $\begin{array}{l}\text { Cost-effectiveness of } \\
\text { sucroferric } \\
\text { exyhydroxide(PA21) } \\
\text { versus sevelamer } \\
\text { carbonate (SC) in } \\
\text { patients receiving } \\
\text { dialysis for } \\
\text { hyperphosphataemia } \\
\text { in Scotland }\end{array}$ & $\begin{array}{l}\text { Vifor Pharma } \\
\text { Ltd }\end{array}$ & $\begin{array}{l}\text { Lifetime Markov cohort model to assess } \\
\text { cost-effectiveness of therapy with PA21 } \\
\text { versus SC with six health states and cycle } \\
\text { length of 1-month and half-cycle } \\
\text { correction. Mean age at model entry } 56 \\
\text { years with adopted model lifetime } \\
\text { represented by a maximum of } 44 \text { years } \\
\text { (528 cycles), corresponding to age } 100 \\
\text { years. Outcomes: undiscounted survival, } \\
\text { QALYs and cost per QALY gained[Note: Us } \\
\text { data indicated that for patients with } \\
\text { dialysis at age } 40-44 \text { years expected } \\
\text { survival 8-years; for those aged 60-64 years } \\
\text { survival approximately } 4.5 \text { years]. Results: } \\
\text { average base case survival 7.61 years. } \\
\text { Incremental QALY gain } 0.009 \text { QALYS in } \\
\text { favor of SC strategy and total cost } \\
\text { difference (in favor of PA21) was f1,609. }\end{array}$ & $\begin{array}{l}\text { No testable } \\
\text { hypotheses or } \\
\text { consideration given to } \\
\text { how the claims might } \\
\text { be evaluated in a } \\
\text { shorter term model. As } \\
\text { the effective } \\
\text { observational period } \\
\text { given average base } \\
\text { case survival is only } \\
7.61 \text { years an } \\
\text { observational study in } \\
\text { warranted given the } \\
\text { clinical benefits of } \\
\text { PA21 (possibly } \\
\text { combined with SC). }\end{array}$ \\
\hline \multicolumn{5}{|c|}{ Systematic Reviews } \\
\hline $\begin{array}{l}\text { Hiligsman et al } \\
30\end{array}$ & $\begin{array}{l}\text { Cost-effectiveness of } \\
\text { drugs for } \\
\text { postmenopausal } \\
\text { osteoporosis }\end{array}$ & & $\begin{array}{l}\text { The review identified } 39 \text { articles that met } \\
\text { inclusion criteria from } 42 \text { articles were that } \\
\text { assessed using full text. Quality assessment } \\
\text { followed the CHEERS checklist. All but one } \\
\text { of the studies used QALYs as the outcome } \\
\text { with model based cost-effectiveness } \\
\text { analyses. A Markov cohort model was used } \\
\text { in } 28 \text { studies with } 8 \text { studies using a } \\
\text { microsimulation model and one using a } \\
\text { discreet-event simulation model. Seven } \\
\text { studies used a fixed time horizon }(3,5 \text { or } 10\end{array}$ & $\begin{array}{l}\text { The review did not } \\
\text { address the issues of } \\
\text { testable claims, the } \\
\text { possibility of } \\
\text { evaluating any claims } \\
\text { or how the claims } \\
\text { might be evaluated by } \\
\text { a formulary } \\
\text { committee. } \\
\text { Application of the } \\
\text { CHEERS instrument }\end{array}$ \\
\hline
\end{tabular}




\begin{tabular}{|c|c|c|c|c|}
\hline & & & $\begin{array}{l}\text { years) with } 32 \text { studies using a lifetime } \\
\text { perspective. Active osteoporotic drugs } \\
\text { were generally cost-effective when } \\
\text { compared to no treatment at commonly } \\
\text { accepted thresholds of around } € 45,000 \text { per } \\
\text { QALY gained. It was not possible to make } \\
\text { recommendations, given heterogeneity of } \\
\text { studies, on relative cost-effectiveness of } \\
\text { drugs. }\end{array}$ & $\begin{array}{l}\text { effectively precluded } \\
\text { these questions being } \\
\text { addressed. }\end{array}$ \\
\hline${\text { Zhang et } \text { al }^{31}}^{31}$ & $\begin{array}{l}\text { Cost-effectiveness of } \\
\text { existing treatment } \\
\text { options for psoriasis }\end{array}$ & & $\begin{array}{l}\text { The review identified } 53 \text { articles that met } \\
\text { inclusion criteria from } 500 \text { articles than } \\
\text { merited a full text review. Quality } \\
\text { assessment was evaluated by application of } \\
\text { the QHES instrument, with the focus on the } \\
\text { drivers of cost-effectiveness instead of } \\
\text { cost-effectiveness outcomes. Overall, } 11 \\
\text { studies used a decision tree framework } 10 \\
\text { a Markov model and } 7 \text { the York } \\
\text { (Woolacott) model }{ }^{\text {i }} \text {. The authors } \\
\text { concluded that most cost-effectiveness } \\
\text { analyses were of low quality- determined } \\
\text { by short time horizons, not using quality } \\
\text { adjusted life years as the effectiveness } \\
\text { measure , failure to include all relevant } \\
\text { resource units or failing to perform a } \\
\text { sensitivity analysis. }\end{array}$ & $\begin{array}{l}\text { The review did not } \\
\text { address the issues of } \\
\text { testable claims, the } \\
\text { possibility of } \\
\text { evaluating any claims } \\
\text { or how the claims } \\
\text { might be evaluated by } \\
\text { a formulary } \\
\text { committee. } \\
\text { Application of the } \\
\text { QHES instrument } \\
\text { effectively precluded } \\
\text { these questions being } \\
\text { addressed. }\end{array}$ \\
\hline $\begin{array}{l}\text { Srivastava et al } \\
33\end{array}$ & $\begin{array}{l}\text { Humanistic and } \\
\text { economic burden of } \\
\text { Chronic Obstructive } \\
\text { Pulmonary Disease } \\
\text { (COPD). }\end{array}$ & GlaxoSmithKline & $\begin{array}{l}\text { A total of } 32 \text { studies reporting humanistic } \\
\text { burden and } 74 \text { economic burden studies } \\
\text { were identified with } 6 \text { studies reporting } \\
\text { both. Outcomes in humanistic studies were } \\
\text { PROs (including HRQoL); the economic } \\
\text { burden was restricted to cost and resource } \\
\text { utilization. }\end{array}$ & $\begin{array}{l}\text { Although focused on } \\
\text { evidence describing } \\
\text { and quantifying the } \\
\text { burden of } \\
\text { symptomatic COPD } \\
\text { the review did not } \\
\text { address the issues of } \\
\text { testable claims (e.g., in } \\
\text { evaluating the burden } \\
\text { of disease), the } \\
\text { possibility of } \\
\text { evaluating any claims } \\
\text { or how the claims } \\
\text { might be evaluated by } \\
\text { a formulary committee } \\
\text { in the management of } \\
\text { gout. }\end{array}$ \\
\hline
\end{tabular}




\begin{tabular}{|c|c|c|c|}
\hline Geng et al $^{34}$ & $\begin{array}{l}\text { Cost-effectiveness of } \\
\text { dideptidyl peptidase-4 } \\
\text { inhibitors for type } 2 \\
\text { diabetes }\end{array}$ & $\begin{array}{l}\text { A total of } 11 \text { studies met the inclusion } \\
\text { criteria following full text review of } 36 \\
\text { articles. Quality assessment followed the } \\
\text { CHEERS checklist. Seven studies used the } \\
\text { Cardiff Diabetes Model, } 3 \text { the UK } \\
\text { Prospective Diabetes Study (UKPDS) and } \\
\text { one the Januvia Diabetes Model. Four } \\
\text { studies were of good quality, six of } \\
\text { moderate and one of low quality. Four } \\
\text { studies were based on a lifetime model and } \\
\text { five based on } 40 \text { years. One of the latter } \\
\text { studies also included } 5 \text { years and the } \\
\text { remaining study } 3 \text { years. Seven of the } \\
\text { studies were funded by manufacturers. All } \\
\text { studies reported outcomes as QALYs per } \\
\text { person. }\end{array}$ & $\begin{array}{l}\text { The review did not } \\
\text { address the issues of } \\
\text { testable claims, the } \\
\text { possibility of } \\
\text { evaluating any claims } \\
\text { or how the claims } \\
\text { might be evaluated by } \\
\text { a formulary } \\
\text { committee. }\end{array}$ \\
\hline Diel et al ${ }^{35}$ & $\begin{array}{l}\text { Cost-effectiveness of } \\
\text { preventive treatment } \\
\text { for tuberculosis in } \\
\text { special high risk } \\
\text { populations }\end{array}$ & $\begin{array}{l}\text { A total of } 24 \text { cost-effectiveness studies } \\
\text { were identified covering six high-risk } \\
\text { groups. Of these, } 20 \text { studies used a Markov } \\
\text { simulation model and one a decision } \\
\text { analytic model. QALYs were the outcome } \\
\text { measure in } 15 \text { studies, with TB case } \\
\text { prevented in } 7 \text { studies. Time frames ranged } \\
\text { from one years to a lifetime. Apart from } 6 \\
\text { studies which did not report a timeframe, } 5 \\
\text { reported a lifetime framework, and } 8 \\
\text { modeled from } 20 \text { to } 40 \text { years. }\end{array}$ & $\begin{array}{l}\text { Apart from a brief } \\
\text { mention of the unlike } \\
\text { possibility of a long } \\
\text { term prospective study } \\
\text { to assess the costs and } \\
\text { effects of preventive } \\
\text { treatment, The review } \\
\text { did not address the } \\
\text { issues of testable } \\
\text { claims, the possibility } \\
\text { of evaluating any } \\
\text { claims or how the } \\
\text { claims might be } \\
\text { evaluated by a } \\
\text { formulary committee. }\end{array}$ \\
\hline Shields et al ${ }^{36}$ & $\begin{array}{l}\text { Economic and } \\
\text { humanistic burden of } \\
\text { gout }\end{array}$ & $\begin{array}{l}\text { A total of } 39 \text { studies met inclusion criteria, } \\
17 \text { and } 26 \text { respectively were relevant to } \\
\text { economic and humanistic burden of gout. } \\
\text { No mention of application of a quality } \\
\text { checklist. The economic burden was } \\
\text { restricted to cost studies; the humanistic } \\
\text { burden on health related quality of life. } \\
\text { Generic HRQoL measures were most } \\
\text { frequently reported applied: HAQ-DI ( } n=6 \text { ), } \\
\text { HAQ-II ( } n=3 \text { ) and SF-36 ( } n=12 \text { ). Gout } \\
\text { specific measures; GAQ-GI ( }=2 \text { and GIS } \\
\text { (n=3). }\end{array}$ & $\begin{array}{l}\text { Although focused on } \\
\text { evidence describing } \\
\text { and quantifying the } \\
\text { burden of gout, the } \\
\text { review did not } \\
\text { address the issues of } \\
\text { testable claims (e.g., in } \\
\text { evaluating the burden } \\
\text { of disease), the } \\
\text { possibility of } \\
\text { evaluating any claims } \\
\text { or how the claims } \\
\text { might be evaluated by }\end{array}$ \\
\hline
\end{tabular}




\begin{tabular}{|c|c|c|c|c|}
\hline & & & & $\begin{array}{l}\text { a formulary committee } \\
\text { in the management of } \\
\text { gout. }\end{array}$ \\
\hline Zakiyah et al ${ }^{37}$ & $\begin{array}{l}\text { Cost-effectiveness of } \\
\text { screening diagnosis } \\
\text { and treatment options } \\
\text { in pre-eclampsia }\end{array}$ & & $\begin{array}{l}\text { The review identified } 6 \text { studies that met } \\
\text { inclusion criteria from } 8 \text { full text reviews. } \\
\text { Five of these were economic revaluations } \\
\text { and one a budget impact analysis. Quality } \\
\text { assessment was evaluated by application of } \\
\text { the CHEERS checklist. Four studies used a } \\
\text { decision model and two a trial based cost } \\
\text { effectiveness analysis (with } 2 \text { studies using } \\
\text { a } 30 \text { year time horizon). No unequivocal } \\
\text { conclusions could be drawn as to cost- } \\
\text { effective care in pre-eclampsia or the cost- } \\
\text { effectiveness of biomarkers for pre- } \\
\text { eclampsia }\end{array}$ & $\begin{array}{l}\text { The review did not } \\
\text { address the issues of } \\
\text { testable claims, the } \\
\text { possibility of } \\
\text { evaluating any claims } \\
\text { or how the claims } \\
\text { might be evaluated by } \\
\text { a formulary } \\
\text { committee. Even so, } \\
\text { the budget impact } \\
\text { analysis and trial based } \\
\text { evaluations could have } \\
\text { been evaluated in } \\
\text { these terms. }\end{array}$ \\
\hline $\begin{array}{l}\text { Poonawalla et } \\
\text { al }^{38}\end{array}$ & $\begin{array}{l}\text { Cost-effectiveness of } \\
\text { chemotherapeutic } \\
\text { agents and targeted } \\
\text { biologics in ovarian } \\
\text { cancer }\end{array}$ & & $\begin{array}{l}\text { A total of } 73 \text { full text reviews yielded } 28 \\
\text { publications for inclusion. Quality } \\
\text { assessment used the QHES checklist. } \\
\text { Covering a period of } 18 \text { years (1996-2014) } \\
\text { made comparisons between studies } \\
\text { difficult and any consensus. Cost per life } \\
\text { year gained (LYG) was the outcome } \\
\text { measure in } 15 \text { of the studies; cost per QALY } \\
\text { gained the outcome in } 13 \text { of the studies. }\end{array}$ & $\begin{array}{l}\text { The range of studies } \\
\text { included make any } \\
\text { general conclusion } \\
\text { difficult. Even so, the } \\
\text { review did not address } \\
\text { the issues of testable } \\
\text { claims, the possibility } \\
\text { of evaluating any } \\
\text { claims or how the } \\
\text { claims might be } \\
\text { evaluated by a } \\
\text { formulary committee. }\end{array}$ \\
\hline \multicolumn{5}{|l|}{ Review Article } \\
\hline Fleeman et al $^{39}$ & $\begin{array}{l}\text { Pertuzamab in } \\
\text { combination with } \\
\text { trastuzumab and } \\
\text { docetaxel for HER-2 } \\
\text { metaststic or locally } \\
\text { recurrent } \\
\text { unresectable breast } \\
\text { cancer }\end{array}$ & $\begin{array}{l}\text { NICE Single } \\
\text { Technology } \\
\text { Appraisal }\end{array}$ & $\begin{array}{l}\text { Roche was asked to submit evidence for } \\
\text { the clinical and effectiveness of } \\
\text { pertuzumab + trastuzumab + docetaxel vs. } \\
\text { placebo + trastuzumab + docetaxel for the } \\
\text { treatmentof human epidermal growth } \\
\text { factor in HER-2 metastatic or locally } \\
\text { recurrent or resectable breast cancer based } \\
\text { on one ongoing RCT (CLEOPATRA). While } \\
\text { the ERG judged the trial to be of good } \\
\text { methodological quality the overall survival } \\
\text { data were problematic as the trial was } \\
\text { ongoing. Also, the protocol for the trial did } \\
\text { not reflect current clinical practice with }\end{array}$ & $\begin{array}{l}\text { The NICE appraisal } \\
\text { made no reference to } \\
\text { the possibility of } \\
\text { testable claims or the } \\
\text { possibility of } \\
\text { evaluating claims for } \\
\text { the product in an NHS } \\
\text { environment. }\end{array}$ \\
\hline
\end{tabular}




\begin{tabular}{|c|c|c|c|c|}
\hline & & & $\begin{array}{l}\text { trastuzumab. The cost-effectiveness case } \\
\text { rested on a lifetime partitioned survival } \\
\text { model with } 3 \text { health states. Given the lack } \\
\text { of maturity in the overall survival data } \\
\text { application of the model was limited. A } \\
\text { provisional extrapolation by the WERG for } \\
\text { overall survival yielded a lower survival rate } \\
\text { and difference between the two arms. The } \\
\text { estimated ICERs were larger than for the } \\
\text { manufacturer's base case. It was deemed } \\
\text { impossible to set a price for pertuzamab. } \\
\text { While the Appraisal Committee rejected } \\
\text { the product a further decision was pending } \\
\text { at the time of publication }\end{array}$ & \\
\hline $\begin{array}{l}\text { Greenhalgh et } \\
\text { al }^{40}\end{array}$ & $\begin{array}{l}\text { Eribulin for advanced } \\
\text { or metastatic breast } \\
\text { cancer }\end{array}$ & $\begin{array}{l}\text { NICE Single } \\
\text { Technology } \\
\text { Appraisal }\end{array}$ & & $\begin{array}{l}\text { The NICE appraisal } \\
\text { made no reference to } \\
\text { the possibility of } \\
\text { testable claims or the } \\
\text { possibility of } \\
\text { evaluating claims for } \\
\text { the product in an NHS } \\
\text { environment }\end{array}$ \\
\hline Holmes et al ${ }^{41}$ & $\begin{array}{l}\text { alteplase for acute } \\
\text { ischaemic stroke }\end{array}$ & $\begin{array}{l}\text { NICE Single } \\
\text { Technology } \\
\text { Appraisal }\end{array}$ & $\begin{array}{l}\text { Boehringer Ingelheim GmbH was asked to } \\
\text { submit evidence for the clinical and cost- } \\
\text { effectiveness of alteplase for the } \\
\text { prevention of strokes within a } 0-4.5 \text { hour } \\
\text { window from the onset of stroke } \\
\text { symptoms with the comparator of standard } \\
\text { medical and supportive management that } \\
\text { did not include alteplase. A lifetime model } \\
\text { was utilized generating cost-per-QALY } \\
\text { estimates as the primary endpoint. The } \\
\text { ERG generally accepted the clinical claims } \\
\text { and the modeled cost-effectiveness case. } \\
\text { Treatment effect was captured by } \\
\text { modeling the distribution of patients } \\
\text { between the health states dependent, } \\
\text { independent, dead at } 6 \text { months following } \\
\text { treatment. Probabilities of transition } \\
\text { between the health states beyond } 6 \\
\text { months were modelled from a stroke } \\
\text { registry, with patients remaining in that } \\
\text { health state until they experienced a } \\
\text { recurrent stroke or died. Age specific }\end{array}$ & $\begin{array}{l}\text { Although there were } \\
\text { opportunities given } \\
\text { the structure of the } \\
\text { modelling to evaluate } \\
\text { claims at three or six } \\
\text { monthly intervals, the } \\
\text { NICE appraisal made } \\
\text { no reference to the } \\
\text { possibility of testable } \\
\text { claims or the } \\
\text { possibility of } \\
\text { evaluating claims for } \\
\text { the product in an NHS } \\
\text { environment }\end{array}$ \\
\hline
\end{tabular}




\begin{tabular}{|c|c|c|c|c|}
\hline & & & $\begin{array}{l}\text { mortality risk for those without or } \\
\text { experiencing a recurrent stroke were } \\
\text { applied. The product was recommended } \\
\text { for marketing authorization. }\end{array}$ & \\
\hline Haas et al ${ }^{42}$ & $\begin{array}{l}\text { Pharmacologic } \\
\text { management of } \\
\text { chronic lower back } \\
\text { pain }\end{array}$ & & $\begin{array}{l}\text { A total of } 7 \text { studies were identified. Two of } \\
\text { these were modelled studies. Both scored } \\
\text { highly on the QHES; other studies were } \\
\text { considered poor due to lack of good quality } \\
\text { clinical evidence. Most common outcome } \\
\text { measures were pain and disability. In the } \\
\text { two studies that used a reference case } \\
\text { semi-Markov model the QALYs were } \\
\text { measured indirectly using a transfer to } \\
\text { utilities regression equation. Neither model } \\
\text { specified the ICER timeframe. The authors } \\
\text { concluded that in the absence of RCT data, } \\
\text { economic models should be used to } \\
\text { estimate future costs and outcomes using } \\
\text { robust methods. }\end{array}$ & $\begin{array}{l}\text { The review did not } \\
\text { address the issues of } \\
\text { testable claims, the } \\
\text { possibility of } \\
\text { evaluating any claims } \\
\text { or how the claims } \\
\text { might be evaluated by } \\
\text { a formulary } \\
\text { committee. }\end{array}$ \\
\hline Wade et al $^{43}$ & $\begin{array}{l}\text { Aflibercept in } \\
\text { combination with } \\
\text { irinotecan and FOLFIRI } \\
\text { for metastatic } \\
\text { colorectal cancer }\end{array}$ & $\begin{array}{l}\text { NICE Single } \\
\text { Technology } \\
\text { Appraisal }\end{array}$ & $\begin{array}{l}\text { Sanofi was asked to submit clinical and } \\
\text { cost-effectiveness evidence for aflibercept } \\
\text { in combination with irinotecan and } \\
\text { fluorouracil for treatment of metastatic } \\
\text { colorectal cancer. The clinical data were } \\
\text { from one RCT that compared aflibercept + } \\
\text { FOLFIRI with placebo + FOLFIRI. The RCT } \\
\text { found a small but significant difference in } \\
\text { median overall survival and progression } \\
\text { free survival. The ERG considered the } \\
\text { manufacturer's extrapolation of survival } \\
\text { curves to } 15 \text { years to be excessive, instead } \\
\text { truncating the analysis to } 5 \text { years to reflect } \\
\text { a more realistic survivorship profile. Cost- } \\
\text { effectiveness was based on a 3-state } \\
\text { Markov model with a } 15 \text { year time horizon; } \\
\text { outcomes were cost-per-QALY. A major } \\
\text { concern was with the impact of adverse } \\
\text { events on continuation and HRQoL r The } \\
\text { ERG defined an alternative base case which } \\
\text { increased the ICER to f54,368 per QALY. } \\
\text { The product was not recommended; a } \\
\text { decision upheld on appeal. }\end{array}$ & $\begin{array}{l}\text { The NICE appraisal } \\
\text { made no reference to } \\
\text { the possibility of } \\
\text { testable claims or the } \\
\text { possibility of } \\
\text { evaluating claims for } \\
\text { the product in an NHS } \\
\text { environment }\end{array}$ \\
\hline Stevenson et al & Nalmefene for & NICE Single & Lundbeck was asked to submit evidence for & The NICE appraisal \\
\hline
\end{tabular}




\begin{tabular}{|c|c|c|c|c|}
\hline 44 & $\begin{array}{l}\text { reducing alcohol } \\
\text { consumption }\end{array}$ & $\begin{array}{l}\text { Technology } \\
\text { Appraisal }\end{array}$ & $\begin{array}{l}\text { the clinical and cost-effectiveness of } \\
\text { nalmefene for reducing alcohol } \\
\text { consumption in people with alcohol } \\
\text { dependence. Clinical evidence was from } 3 \\
\text { phase III trials that compared nalmefene } \\
\text { plus psychosocial support with placebo } \\
\text { plus psychosocial support. Cost- } \\
\text { effectiveness claims were based on Markov } \\
\text { cohort model with a timeframe of } 5 \text { years. } \\
\text { The model comprised a one year short } \\
\text { term phase (cycle length1 month) and a } \\
\text { long term phase (cycle length } 1 \text { year). } \\
\text { Utility in the first year was from trial-based } \\
\text { pooled EQ-5D results; in the long term } \\
\text { utility was assumed to be a function of } \\
\text { drinking status. The ERG reworked the } \\
\text { model, in part to draw comparisons with } \\
\text { the NICE CG15 recommendations for } \\
\text { psychosocial interventions. Although based } \\
\text { on limited data (with one comparison } \\
\text { dropped) the reworked ICERS were little } \\
\text { different from those first submitted. The } \\
\text { methodological issue that had the largest } \\
\text { impact was the fact that the pivotal RCTs } \\
\text { did not use the psychosocial support listed } \\
\text { in the scope. Nalmefene, was } \\
\text { recommended within its marketing } \\
\text { authorization, prescribed in conjunction } \\
\text { with continuous psychosocial support.. }\end{array}$ & $\begin{array}{l}\text { made no reference to } \\
\text { the possibility of } \\
\text { testable claims or the } \\
\text { possibility of } \\
\text { evaluating claims for } \\
\text { the product in an NHS } \\
\text { environment. }\end{array}$ \\
\hline Fleeman et al $^{45}$ & $\begin{array}{l}\text { Dabrafenib to treating } \\
\text { unresectable, } \\
\text { advanced or } \\
\text { metastatic BRAF V600 } \\
\text { for mutation-positive } \\
\text { melanoma }\end{array}$ & $\begin{array}{l}\text { NICE Single } \\
\text { Technology } \\
\text { Appraisal }\end{array}$ & $\begin{array}{l}\text { GlazoSmithkline was asked to submit } \\
\text { evidence for the clinicakl and cost- } \\
\text { effectiveness of dabrafenib. Although the } \\
\text { ongoing BREAK-3 trial compared } \\
\text { dabrafenib with dacarbazine, the Evidence } \\
\text { Review Group (ERG) considered } \\
\text { vemurafenib to be the appropriate } \\
\text { comparator. Evidence for vemurafenib was } \\
\text { taken from the BRIM-3 trial where the } \\
\text { comparator was dacarbazine. The company } \\
\text { presented an indirect treatment } \\
\text { comparison model that demonstrated no } \\
\text { clinical difference between the two } \\
\text { products. The ERG rejected the } \\
\text { comparison, mainly for the validity of the } \\
\text { assumptions. This undermined modeled }\end{array}$ & $\begin{array}{l}\text { The NICE appraisal } \\
\text { made no reference to } \\
\text { the possibility of } \\
\text { testable claims or the } \\
\text { possibility of } \\
\text { evaluating claims for } \\
\text { the comparator } \\
\text { products in an NHS } \\
\text { environment for either } \\
\text { clinical or cost- } \\
\text { effectiveness claims. }\end{array}$ \\
\hline
\end{tabular}




\begin{tabular}{|c|c|c|c|c|}
\hline & & & $\begin{array}{l}\text { claims. The model used to establish cost- } \\
\text { effectiveness had additional issues that } \\
\text { undermined its credibility. A 30-year } \\
\text { Markov model was presented with } 3 \text { states } \\
\text { and a cycle length of } 1 \text { week. The ERG } \\
\text { rejected the company's claims for long- } \\
\text { term survival which were significant in } \\
\text { making the case for the company's product } \\
\text { vs. the comparator. There were limited } \\
\text { data on HRQoL. The company submitted } \\
\text { evidence did not conform to the NICE } \\
\text { methodological guidelines with an } \\
\text { inappropriate analysis of the evidence. The } \\
\text { two products were considered to be } \\
\text { identical in clinical practice }\end{array}$ & \\
\hline Simpson et al ${ }^{46}$ & $\begin{array}{l}\text { Sipulencel-T for } \\
\text { metastatic hormone- } \\
\text { relapsed prostate } \\
\text { cancer }\end{array}$ & $\begin{array}{l}\text { NICE Single } \\
\text { Technology } \\
\text { Appraisal }\end{array}$ & $\begin{array}{l}\text { Dendreon, the manufacturer of sipuleucel- } \\
\text { T was asked to submit evidence for clinical } \\
\text { and cost-effectiveness the product where } \\
\text { the comparator was abiraterone acetate } \\
\text { (AA) or best supportive care (BSC). Based } \\
\text { on the balance of evidence presented, the } \\
\text { ERG concluded that sipuleucel-T in two of } \\
\text { three trials improved overall survival but } \\
\text { none showed prolonged time to disease } \\
\text { progression. The Advisory Committee } \\
\text { concluded that the product improved } \\
\text { overall survival compared to APC-PBO. } \\
\text { However, in the low PSA-subgroup (which } \\
\text { was considered the relevant group for } \\
\text { marketing authorization) there was no } \\
\text { evidence for superiority in overall survival. } \\
\text { The company cost-effectiveness model } \\
\text { considered both the whole population as } \\
\text { well as subgroups. A lifetime horizon was } \\
\text { assumed with monthly time cycles with } \\
\text { parametric survival curves for overall } \\
\text { survival. The primary outcome was QALYs } \\
\text { gained. The ERG had a number of concerns } \\
\text { with the model and undertook a separate } \\
\text { modelling exercise on a set of nine } \\
\text { preferred assumptions. The ERGs } \\
\text { probabilistic sensitivity analysis suggested } \\
\text { either a zero probability or a very low } \\
\text { probability of the product meeting a }\end{array}$ & $\begin{array}{l}\text { The NICE guidance } \\
\text { recommended against } \\
\text { the product. The NICE } \\
\text { appraisal made no } \\
\text { reference to the } \\
\text { possibility of testable } \\
\text { claims or the } \\
\text { possibility of further } \\
\text { evaluating claims for } \\
\text { the product in an NHS } \\
\text { environment for either } \\
\text { clinical or cost- } \\
\text { effectiveness claims. }\end{array}$ \\
\hline
\end{tabular}




\begin{tabular}{|c|c|c|c|c|}
\hline & & & $£ 50,000$ threshold & \\
\hline $\begin{array}{l}\text { Giannopoulou } \\
\text { et al }{ }^{47}\end{array}$ & $\begin{array}{l}\text { Ipilimumab for } \\
\text { previously untreated } \\
\text { unresectable } \\
\text { malignant melanoma }\end{array}$ & $\begin{array}{l}\text { NICE Single } \\
\text { Technology } \\
\text { Appraisal }\end{array}$ & 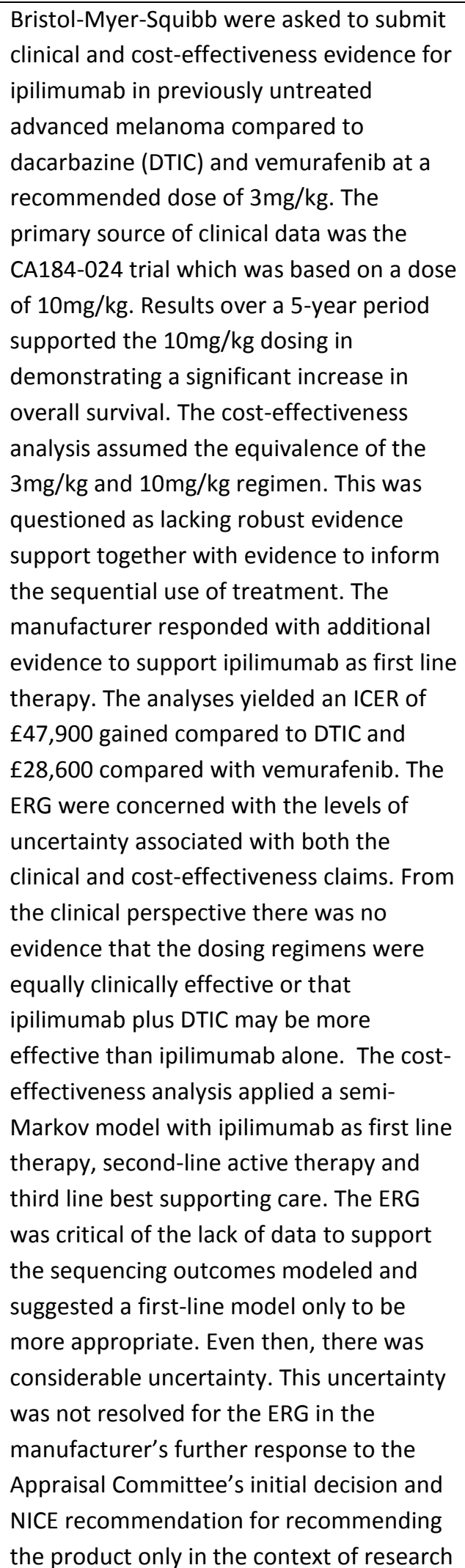 & $\begin{array}{l}\text { Although the ERG } \\
\text { admitted considerable } \\
\text { uncertainty with } \\
\text { respect both to clinical } \\
\text { claims for equivalence } \\
\text { in dosing and in } \\
\text { combination therapy } \\
\text { together with the lack } \\
\text { of clinical evidence to } \\
\text { support treatment } \\
\text { sequencing, Even with } \\
\text { the short survival time } \\
\text { frames with } \\
\text { unresectable } \\
\text { melanoma the NICE } \\
\text { appraisal made no } \\
\text { reference to the } \\
\text { possibility of testable } \\
\text { claims or the } \\
\text { possibility of } \\
\text { evaluating claims for } \\
\text { the product in an NHS } \\
\text { environment for either } \\
\text { the clinical or cost- } \\
\text { effectiveness claims. }\end{array}$ \\
\hline
\end{tabular}




\begin{tabular}{|l|l|l|}
\hline & & $\begin{array}{l}\text { as part of a clinical study. Marketing } \\
\text { approval was finally given after a discount } \\
\text { was agreed with the manufacturer under } \\
\text { the market access scheme. IT was admitted } \\
\text { that there were concerns that the appraisal } \\
\text { process was initiated before there was } \\
\text { sufficient evidence to inform the cost- } \\
\text { effectiveness assessment. }\end{array}$ \\
\hline
\end{tabular}

